\title{
EXPLORATION AND SELECTION OF RHIZOBACTERIA THAT INHIBIT Phytophthora capsici IN VITRO
}

\author{
Aulia Zakia ${ }^{1}$, Satriyas Ilyas ${ }^{2}$, Candra Budiman ${ }^{2}$, Syamsuddin $^{3}$, \& Dyah Manohara ${ }^{4}$ \\ ${ }^{1}$ Student of Seed Science and Technology, Postgraduate School, Bogor Agricultural University, Indonesia \\ ${ }^{2}$ Agronomy and Horticulture Department, Faculty of Agriculture, Bogor Agricultural University, Indonesia \\ Jl. Meranti Kampus IPB Dramaga Bogor 16680 \\ ${ }^{3}$ Departmen of Agroecotechnology, Faculty of Agriculture, Syah Kuala University, Darussalam Campus, \\ Banda Aceh, Indonesia \\ J1. Tgk. Hasan Krueng Kalee No.3 Kopelma Darussalam Syiah Kuala Kota Banda Aceh 23111 \\ ${ }^{4}$ Balai Penelitian Tanaman Rempah dan Obat \\ Jl. Tentara Pelajar No. 3A Menteng Bogor Barat \\ e-mail:dyah_manohara@yahoo.com
}

\begin{abstract}
Exploration and selection of Rhizobacteria that inhibit Phytophthora capsici in vitro. Phytophthora capsici, a seed borne and the soil borne fungal pathogen is the cause of phytophthora blight on chili. The disease is difficult to control because of the unavailability of resistant varieties in Indonesia. The purpose of this study was to obtain isolates of rhizobacteria which have the ability to inhibit $P$. capsici in vitro. Exploration of rhizobacteria was conducted in centers of chili production in East Java (Malang, Batu, and Kediri) and West Java (Bogor). In one location, chili plant that had symptoms of phytophthora blight disease and a healthy plant next to it were chosen as samples to isolate $P$. capsici and the rhizobacteria. The rhizobacteria were isolated on NA, TSA, and TSAP (TSA with heated sample). Samples of diseased plants were used in isolation of $P$. capsici on V8 agar. The inhibition and compatibility of the rhizobacteria to inhibit $P$. capsici in vitro were tested by dual culture method. In this experiment, it was obtained 252 isolates of rhizobacteria and one isolate of $P$. capsici. Isolates of rhizobacteria with high to medium inhibition were $\mathrm{E} 1, \mathrm{E} 3 \mathrm{C} 2$, and $\mathrm{F} 2 \mathrm{~B} 1$ respectively. All three isolates were then combined and tested against $P$. capsici in vitro. The highest inhibition was indicated by four isolate and combination of isolates, which were E1 isolate (58\%), the combination of E1 + E3C2 isolates (58\%), E1 + F2B1 (60\%) and E1 + E3C2 + F2B1 (58\%).
\end{abstract}

Key words: dual culture, inhibition, phytophthora blight, Rhizobcteria isolate

\begin{abstract}
ABSTRAK
Eksplorasi dan penapisan Rizobakteri penghambat Phytophthora capsici secara in vitro. Phytophthora capsici, cendawan patogen terbawa benih dan tular tanah dalah penyebab penyakit busuk phytophthora pada cabai. Penyakit ini sulit dikemdalikan karena belum tersedianya varietas yang resisten di Indonesia. Tujuan penelitian ini adalah mendapatkan isolat rizobakteri yang dapat menghambat $P$. capsici secara in vitro. Eksplorasi rizobakteri dilakukan di sentra produksi cabai Jawa Timur (Malang, Batu, dan Kediri) dan Jawa Barat (Bogor). Setiap lokasi diambil satu sampel tanaman sehat dan satu sampel tanaman sakit bergejala busuk phytophthora yang bersebelahan. Sampel tanaman sehat digunakan dalam isolasi rizobakteri pada media NA, TSA dan TSAP (media TSA dengan sampel dipanaskan). Sampel tanaman sakit digunakan dalam isolasi P. capsici pada media agar V8. Uji daya hambat dan uji kompatibilitas rizobakteri dalam menghambat P. capsici secara in vitro diakukan dengan metode dua biakan (dual culture). Berdasarkan hasil eksplorasi diperoleh 252 isolat rizobakteri; 22 isolat diantaranya diduga memiliki kemampuan menghambat $P$. capsici secara in vitro, dan satu isolat $P$. capsici. Isolat rizobakteri dengan daya hambat tertinggi sampai sedang, berturut-turut adalah isolat E1, E3C2 dan F2B1. Hasil uji kompatibilitas tiga isolat rizobakteri terbaik menunjukkan daya hambat tertinggi serta zona penghambat terlebar terhadap P.capsici yaitu kombinasi isolat E1+F2B1 (60\%), isolat $\mathrm{E} 1$ (58\%), kombinasi isolat $\mathrm{E} 1+\mathrm{E} 3 \mathrm{C} 2$ (58\%), dan $\mathrm{E} 1+\mathrm{E} 3 \mathrm{C} 2+\mathrm{F} 2 \mathrm{~B} 1$ (58\%).
\end{abstract}

Kata kunci: busuk phytophthora, daya hambat, dual culture. isolat rizobakteri 


\section{INTRODUCTION}

Chili palnting main problem the attack of phytophthora blight which caused by Phytophthora capcisi (Louws et al., 2002), and carried by seeds (seed borne) (Agarwal \& Sinclair, 1997). According to Manohara (1998), as a soil-borne pathogen, P. capsici is able to survive and spread to healthy plants through the soil.

P. capsici, the cause of phytophthora blight, has been shown to reduce the yield of paprika, red chili and other vegetable crops, not only in Indonesia but also in several other countries (Babadoost, 2004; Hausbeck \& Lamour, 2004; Lim \& Kim, 2010). The spread of phytophthora blight pathogens can be through water, winds that occur during rain, plant material, livestock/ animals, humans and agricultural tools (Manohara et al., 2005). This disease is still difficult to control because of the unavailability of resistant varieties and limited control methods. According to (Syamsuddin 2010), this pathogen is pathogenic to 25 chili genotypes with stem rot symptoms, five genotypes with the highest disease intensity are Taro F1, Hot Pepper Tornado, F1 Hybrid Chilli, Bintoro, and Marconi hot with 70"92\% attack percentage.

The use of biological control agents as an alternative to the use of chemical pesticides is increasingly being developed in line with increasing awareness of the effects of synthetic chemical pesticides. Rhizobacteria originating from the rhizosphere of plants that are biologically fused with their ecosystems have the ability to specifically suppress various plant diseases (Yamaguchi, 1996). In contrast to the side effects of continuous use of chemical fertilizers, growth-promoting rhizobacteria can improve soil structure and leave no toxic effects when applied to the soil (Babalola, 2010).

Rhizobacteria are able to act as antagonists, controlling diseases caused by Phytophthora capsici (Syamsuddin, 2010; Ibrahim et al., 2014; Rosadiah et al., 2015). Rhizobacteria as an antagonist were chosen based on several factors such as the ability of direct antagonism to pathogens, adaptability in the environment and induction of resistance to host plants (Aravind et al., 2008). According to Sutariati et al. (2006b), rhizobacteria can also act as a biocontrol for boosting chili plant growth, through its ability to synthesize phytohormones (IAA) and siderophore. Khan et al. (2009) stated that rhizobacteria have the ability to dissolve phosphates so as to increase nutrient absorption through plant roots. The purpose of this study was to obtain rhizobacterial isolates that could inhibit P. capsici in vitro, the rhizobacteria used as biological agents were isolated from chili plantations in East Java. The Rhizobacteria can later be used in the treatment of seeds before planting.

\section{MATERIALS AND METHODS}

Research Site. The experiment was carried out at Balai Penelitian Tanaman Rempah dan Obat Cimanggu, Bogor City. The experiment was conducted from February 2015 to October 2015.

Exploration of Rhizobacteria and P. capsici in Chili Plantations. The experiment began with an exploration of rhizobacteria and P. capsici in chili plantations in East Java, namely Kab. Kediri, Kab. Malang, and Kota Batu. Exploration was also carried out in the Bogor Regency of West Java as an evaluation of previous research (Syamsuddin, 2010). Plants used as samples for the isolation of P. capsici, which is a sick plant with a stem rot. Healthy plants adjacent to sick plant samples were taken as samples for isolation of rhizobacteria. This is done with the assumption that there are rhizobacteria in the roots of healthy plants that can inhibit $P$. capsici infection.

A sampling of rhizosphere or rhizoplane soil refers to BBPPSLP (2007) by determining the plants to be excavated. The soil surface under the canopy is cleaned from leaves or litter. Then the soil under the canopy around the roots is dug slowly with a ground spoon or spatula. The roots are separated from large blocks of soil, but the soil attached to the roots is left unchecked. The canopy of the plant near the base of the root is cut, then the root and the attached soil are put into plastic and wrapped in newsprint, then put into plastic again, labeled, and stored in an ice box. The second rhizosphere or rhizoplane sampling from different types of plants is done after all the equipment is clean and sterile. Plant samples and rhizosphere soil are stored at room temperature $\left(25^{\circ} \mathrm{C}\right)$ until they are used as insulation material.

Isolation of Rhizobacteria and $P$. capsici from Exploration Results Isolation of Rhizobacteria. Isolation of rhizobacteria using a combination of serial dilution methods and pouring methods (Madigan et al., 2003), as well as a method that has been modified by Syamsuddin (2010). Rhizosphere or rhizoplane soil samples were $10 \mathrm{~g}$, suspended in $90 \mathrm{~mL}$ sterile distilled water, and shaken with a shaker for 60 minutes. After that, serial dilution is performed at the $10^{-4}$ and $10^{-5}$ dilution levels. Each dilution level was taken $0.5 \mathrm{~mL}$, 
and poured into a petri dish, then added with nutrient agar (NA) media, tryptic soy agar (TSA), and King's B (Madigan et al., 2003). Modifications were made by pouring $0.5 \mathrm{~mL}$ of rhizosphere soil suspension which had been heated in a water bath at $80^{\circ} \mathrm{C}$ for 30 minutes into a petri dish, then adding TSA media and coded TSAP (TSA media with heated samples) (Syamsuddin, 2010). The obtained bacterial culture was incubated in a room of $27^{\circ} \mathrm{C}$ for 48 hours. Each sample was made in five replications. Each type of growing colony is isolated and made pure culture. Pure rhizobacterial isolates are stored in the NA slant media.

Isolation of $\boldsymbol{P}$. capsici. Isolation of $P$. capsici using a method developed by Manohara (1988). Part of the plant is sick with symptoms that are still fresh, cut into pieces (size $0.5 \mathrm{~cm}^{2}$ ), washed with running water for 15-30 minutes. Sterilize the cut surfaces of sick plants with $70 \%$ alcohol for 3 minutes and wash sterile water three times, then dry them in a laminar air flow cabinet (LAFC). Diseased plant pieces are placed on the surface of the water agar (WA) media and incubated at room temperature with continuous lighting for 2-3 days. Purification of $P$. capsici isolates using V8 agar media, with composition: $800 \mathrm{~mL}$ of distilled water, $200 \mathrm{~mL}$ of $\mathrm{V} 8$ juice, $1 \mathrm{~g}$ of $\mathrm{CaCO} 3$, and $20 \mathrm{~g}$ of Bacto agar. Isolates of $P$. capsici pure are stored in the medium so that the $\mathrm{V} 8$ is tilted.

Testing of mating type is done using the dual culture method (two cultures) (Manohara 1988). P. capsici isolates to be tested were grown in V8 media, 3 $\mathrm{cm}$ away from the edge of the petri dish. Isolates of Balittro P. capsici collection which have been known to type A1 (isolate K2) or A2 (isolate $\mathrm{S} 1$ ) are inoculated in petri dishes within $3 \mathrm{~cm}$, facing the isolates to be tested. Cultures are incubated at room temperature for 3-5 days in dark conditions. If oospora is formed, the isolate has a mating type that is different from the isolate known for its mating type.

Rhizobacterial Screening Inhibiting the Growth of $P$. capsici in vitro Rhizobacterial Inhibitory Test Against $P$. capsici. The effectiveness of rhizobacteria in inhibiting $P$. capsici uses the dual culture method (two cultures) (Purwantisari \& Hastuti 2009). The test was carried out on potato dextrose agar (PDA) media in a petri dish. The culture of $P$. capsici $(0.5 \mathrm{~cm}$ in diameter $)$ grown on PDA media aged 4-5 days, inoculated $3 \mathrm{~cm}$ from the edge of the petri dish containing PDA media. Each rhizobacterial isolate that was cultured on PDA media (age 2 days), was etched at a distance of $3 \mathrm{~cm}$ from the edge of the petri dish opposite the direction of
P. capsici. Control is made by inoculating P. capsici without rhizobacteria. The culture was incubated in a room temperature of $26-28{ }^{\circ} \mathrm{C}$ for 7 days. Measuring the width of the inhibition zone (clear zone) by rhizobacterial isolates and the growth of $P$. capsici colonies carried out every day. The width of the inhibitory zone was measured using a ruler from scratches extending the cultured isolate to the edge of the facing zone with $P$. capsici isolates. The growth of colonies of $P$. capsici was measured using a ruler from the point of culture cuttings to the outer part. Calculation of percentage of Rhizobacteria inhibition (DH) with Syamsuddin (2010) formula:

$$
\mathrm{DH}(\%)=\frac{(\mathrm{R} 1-\mathrm{R} 2)}{\mathrm{R} 1} \times 100 \%
$$

$\mathrm{R} 1=$ radius of growth of pathogens without rhizobacteria (control)

$\mathrm{R} 2=$ radius the growth of pathogens towards rhizobacteria.

The experiment used a completely randomized design of one factor, namely rhizobacterial isolates. Each treatment was repeated three times. Data of inhibitory power by rhizobacteria was analyzed by $F$ test and if there was a real effect, continued with Duncan Multiple Range Test (DMRT) at the level of 5\%. Rhizobacterial isolates that have the highest inhibitory power of $P$. capsici, then tested for compatibility.

Testing Compatibility of Rhizobacteria Selected. Rhizobacterial isolates selected from Experiment 3a. are compatibility tested using the dual culture method (two cultures) with the paper disc. The first rhizobacteria as a base were grown in NA media, then the second rhizobacteria were planted on paper disc and placed on rhizobacteria base (in NA media). As a control, the opposite is done with the second microbial as a base. Evaluation is seen from the growth of the second microbial, and whether or not a clear zone is formed around the second microbe. The second Rhizobacteria that are able to grow and do not produce clear zones are considered compatible.

Test of hypersensitive reactions of rhizobacteria carried out on tobacco leaves. Hypersensitivity testing was carried out by injecting rhizobacterial isolates grown in sterile water, which had been incubated 24 hours, to tobacco leaves. Observations were made on symptoms of necrosis in tobacco leaves. Isolates that cause symptoms of necrosis indicate that the isolate is a pathogen for plants. 


\section{RESULTS AND DISCUSSION}

Exploration of Rhizobacteria and P. capsici in Chili Plantations. The experimental begins with the isolation of $P$. capsici from chili plants with symptoms of stem rot. Exploration of stem rot-stained chili plants in chili plantations in East Java included Kabupaten Malang, Batu City, and Kabupaten Kediri (Figure 1). The choice of the sampling location is based on several factors, first is the height of the place (high, medium and low). According to Permentan No. 47 / Permentan / OT.140 / 10/2006, highland criteria include high $>700 \mathrm{~m}$ above sea level, moderate terrain 350-700 m above sea level, and lowland $<350 \mathrm{~m}$ above sea level. Secondly, East Java is one of the centers of Indonesian chili producers, besides that, Kabupaten Malang and Kediri are centers of chili production for East Java.

Exploration of stem rot symptomatic chili plants was also carried out in the pepper plantation of Kabupaten Bogor in West Java. Observations in the field showed that chili plants were not found with symptoms of stem rot. This is because exploration takes place when the rainy season will end (March 2015), so many chili plantations are destroyed and then replaced with other horticultural crops. According to Manohara et al. (2005), the attack of $P$. capsici occurs in the rainy season, where the air temperature becomes low and high humidity and supported by adequate nutrition will stimulate the resting structure (dormant structure) of pathogenic fungi $P$. capsici to germinate, so that pathogens can survive more long time in the ground.

Based on four locations (Kabupaten Kediri, Kabupaten Malang, Batu City, and Kabupaten Bogor) a total of 12 samples of healthy plants (for rhizobacterial isolation) and 10 sick plant samples (for isolation of $P$. capsici) were obtained. The number of healthy plant samples and diseased plant samples were not the same, because in two locations (Malang -C- and Bogor - $\mathrm{H}-$ ) there were no phytophthora blight symptoms (Table 1).

Exploration results showed that the varieties used in chili plantations in East Java varied (Table 1), namely large chili and cayenne pepper with various varieties, both hybrid and local varieties (annual). The use of seeds of local varieties themselves is carried out conventionally by leaving the harvest of chili the best conditions, then extracted into seeds and used as seed sources. The history of the land before being used as chili plantations varies, most of which is land that has been used to grow chili for more than three years.
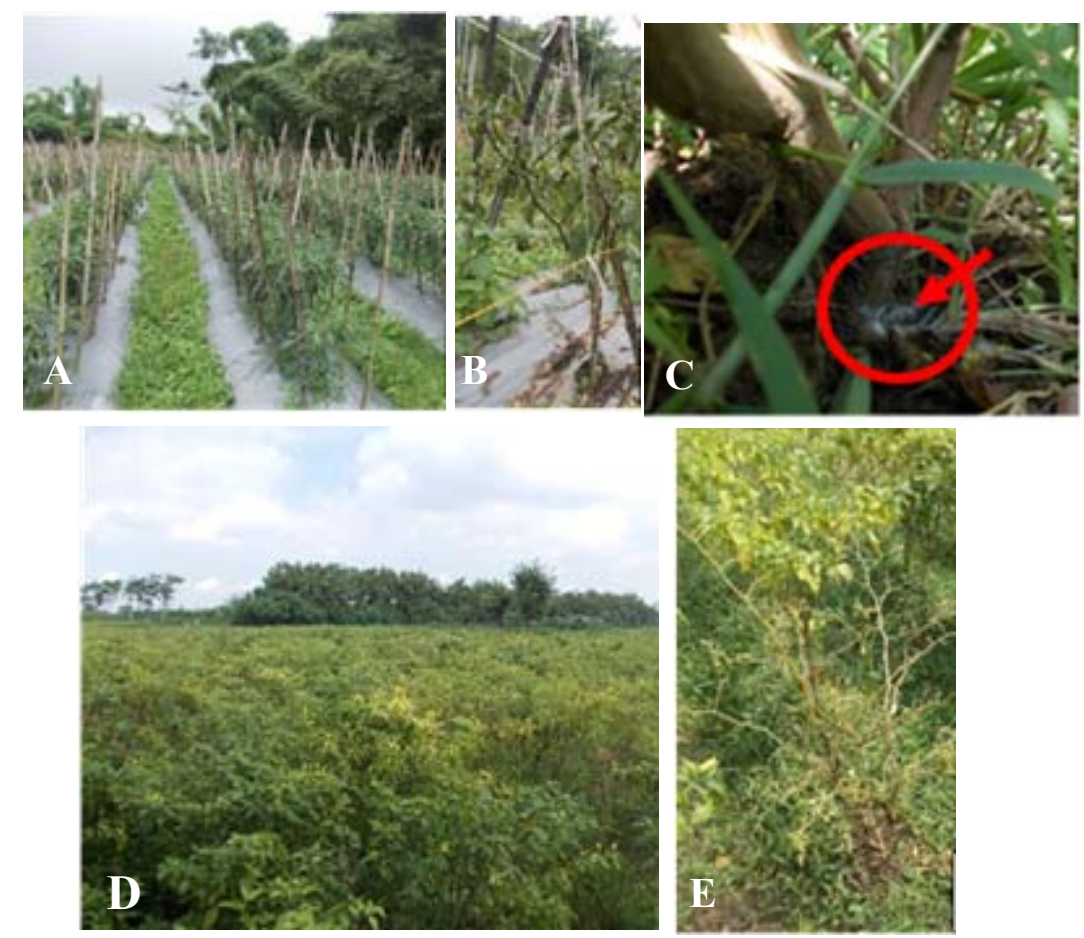

Figure 1.Cultivation of chili in East Java. (A) large chili plants; (B) large chili plants attacked by phytophthora fungus; (C) mycelia found at the base of the stem of the plant; (D) cayenne pepper planting; (E) cayenne plant which is attacked by phytophthora fungus. 
Based on the intensity of phytophthora blight in the field showed that both the seeds of local and hybrid varieties were not resistant to pathogens of $P$. capsici. Besides that, the continuous use of land for chili cultivation also allows pathogens of $P$. capsici to survive in the soil. According to Retnosari et al., (2014), pathogenic of $P$. capsici which is active again can infect all stages of plant growth both at the nursery and in the field.

The intensity of the attack of phytophthora blight caused by pathogenic $P$. capsici varies. Classification of the intensity of attacks is made based on direct observation in the field. Light intensity shows the number of phytophthora decaying chili plants is less than 10 plants, while the heavy attack intensity is more than 20 plants in one area of chili cultivation with a wide variety. The intensity of the attack of $P$. capsici in the field is thought to show the influence of rhizobacterial ability to control phytophthora blight, the heavier the intensity of the attack, the possibility of the rhizobacterial ability to control phytophthora blight gets lower.

\section{Isolation of Rhizobacteria and $P$. capsici from} Exploration Results Isolation of rhizobacteria. Rhizobacterial isolation was carried out based on general characteristics such as the shape of the colony, the shape of the edge of the colony, elevation, and color. According to Aminullah et al., (2015) and Majeed et al., (2015), rhizobacteria generally have characteristics such as round or irregular colony shapes, wavy or flat edges, convex or concave elevations, and have a clear, white, yellow or dark yellow color. Rhizobacterial isolation activities require a relatively long time. Therefore from a number of samples, only eight samples of healthy plants can be isolated on time, while the rest have been damaged. The eight samples represent the height of the place as presented in Table 1. Samples A through sample $\mathrm{G}$ are chili plantations in East Java, while sample $\mathrm{H}$ is chili plantations in West Java (Table 1). Rhizobacterial isolates from West Java did not show the potential to inhibit $P$. capsici in vitro (subsequent experiment), so it was not further investigated.

Rhizobacterial isolation was carried out by extracting the rhizosphere of the roots (rhizoplane) and rhizosphere soil from each sample location with the aim that more bacterial variation was obtained. However, in plain view bacterial variation shows similarities, besides that based on the amount, bacteria that are isolated from rhizosphere soil are relatively less compared to bacteria isolated from rhizoplane. Rhizobacterial isolates are also distinguished based on the bacteria breeding media used, such as the NA, TSA, and TSA media with heated samples (TSAP). Initially the isolation was carried out on King's B media because the isolation results showed similarities with isolates on NA media, so isolation was only carried out on NA, TSA, and TSAP media. The total rhizobacterial isolates obtained were 252 isolates.

Isolation of $\boldsymbol{P}$. capsici. According to Watanabe (2002), $P$. capsici has morphological characteristics including, long and ellipsoidal (oblong) triangular or irregular sporangia, 2-3 papilla/sporangium. Zoospores develop in spongaria, which is ready to break and release sporangiospores. Rarely forms chlamydospora, globose, thick walls, heterotalics. Spore size 20-50 (-55) $\times 15-$ $42.5(-50) \mu \mathrm{m}$; width of papilla $6.2-7.5(-12.5) \mu \mathrm{m}$, height $1.2-6 \mu \mathrm{m}$. Chlamydospore diameter is $35 \mu \mathrm{m}$.

Phytophthora capsici infection was found in all samples of sick chili plants obtained. P. capsici has been found in chili plantations in East Java both in the highlands, medium and low. Of the ten samples of sick plants that have been obtained in exploration, only one was collected. This is because, in addition to P. capsici, there are also other fungi (secondary infections), so it is difficult to get pure isolates. Isolates of $P$. capsici collected were coded $\mathrm{Cb} 6$, originating from Tegalgondo Village, Kecamatan Dau, Kabupaten Malang, East Java (as shown in Figure 2).

Phytophthora capsici is a heterothallic species which requires two types of mating (A1 and A2) to complete its sexual cycle, producing oospore which is useful for survival and producing new individuals (Lamour \& Hausbeck 2001; Meitz et al., 2010; Chaerani et al., 2013). Sexual marriage allows the phytophthora pepper to produce a more virulent derivative than the mother (Wahyuno, 2009). Both types of mating are found in Indonesia, but A2 is detected in frequencies lower than A1 (Manohara et al., 2004). The test results show that $\mathrm{Cb} 6$ isolates are the $\mathrm{A} 2$ type (Figure 3 ). This isolate complements the collection of $P$. capsici isolates from West Java before, with mating type A1 and A2 (Syamsuddin, 2010).

Rhizobacterial Screening Inhibiting the Growth of $P$. capsici in Vitro Rhizobacterial Inhibitory Test Against $P$. capsici. Tests on 252 rhizobacterial isolates produced 22 isolates which could potentially inhibit $P$. capsici in vitro. The 22 rhizobacterial isolates were further tested in several stages so that eight (8) isolates were obtained with the highest percentage of inhibition. The results of the antagonist test with the two culture method showed that eight (8) selected rhizobacterial isolates (E1, E3B1, E3B2, E3C1, E3C2, F2B1, H3A2, and $\mathrm{H} 3 \mathrm{~B}$ ) had different abilities in inhibiting the growth 

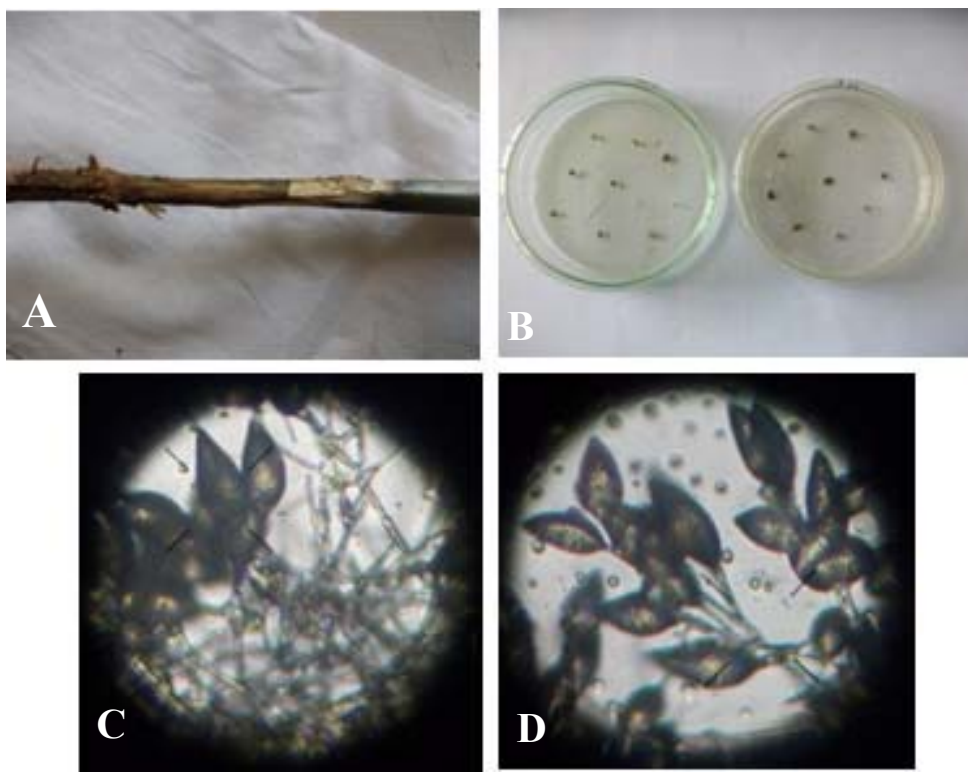

Figure 2. Isolation of Phytophthora capsici. (A) Rot symptom (brown color) at the base of the stem; (B) inoculation of stems with phytophthora blight symptom in WA media; (C) mycelia of P. capsici; (D) sporangia of P. capsici.

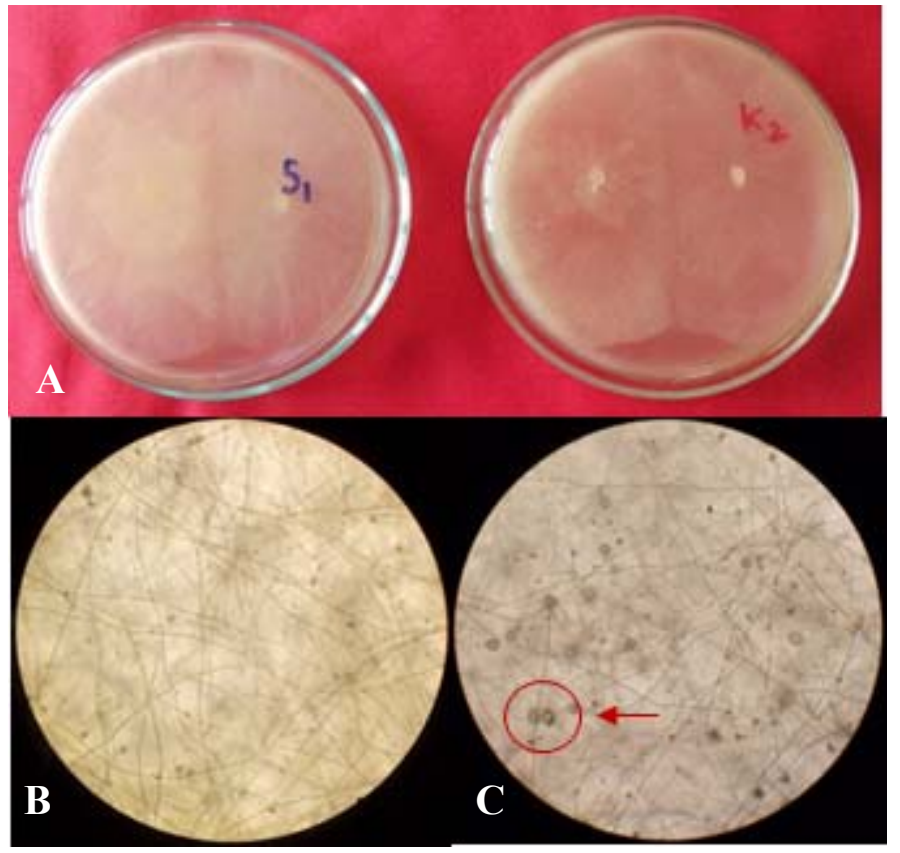

Figure 3. Testing of mating types Phytophthora capsici; (A) test of the two cultures among isolates CB6 with isolates $\mathrm{S} 1$ and $\mathrm{K} 2,(\mathrm{~B})$ is not formed oospore (CB6 isolates with isolates of S1-type A2), (C) the formation of oospore (CB6 isolates with isolates K2-type A1.

of $P$. capsici colonies. Based on 8 rhizobacterial isolates tested, 5 of them showed varying inhibitory power (Table 2), while three other isolates (E3B1, H3B, and H3A2) had small inhibitory power and did not even have inhibitory power. Isolate E1 has the highest inhibitory power of $42 \%$. Four other isolates that have moderate inhibitory power namely isolates $\mathrm{E} 3 \mathrm{~B} 2, \mathrm{E} 3 \mathrm{C} 1, \mathrm{E} 3 \mathrm{C} 2$, and F2B1. This can be seen in the difference in the width of the clear zone of each treatment of rhizobacterial isolates. According to Syamsuddin (2010), 
Table 1. Cultivation of chili for isolates of rhizobacteria and Phytophthora capsici

\begin{tabular}{|c|c|c|c|c|c|}
\hline Sample & Region of origin & $\begin{array}{l}\text { Height of } \\
\text { place }\end{array}$ & Chili varieties & $\begin{array}{l}\text { Attack intensity } \\
\text { of } P \text {. capsici }\end{array}$ & $\begin{array}{l}\text { Number of } \\
\text { rhizobacteria } \\
\text { isolates }\end{array}$ \\
\hline A & $\begin{array}{l}\text { Village Tulungrejo, Sub } \\
\text { district Bumiaji, Kota } \\
\text { Batu, East Jawa }\end{array}$ & High & $\begin{array}{l}\text { Large chili, } \\
\text { varieties unknown }\end{array}$ & Moderate & 26 \\
\hline B & $\begin{array}{c}\text { Village Songgokerto, Sub } \\
\text { district Batu, Kota Batu, } \\
\text { East Jawa }\end{array}$ & High & $\begin{array}{l}\text { Large chili, } \\
\text { varieties Dewanta } \\
\text { (hibrida) }\end{array}$ & Heavy & 24 \\
\hline C & $\begin{array}{l}\text { Village Poncokusumo, } \\
\text { Sub district Poncokusumo, } \\
\text { District Malang, East Jawa }\end{array}$ & High & $\begin{array}{l}\text { Large chili, } \\
\text { Produced by Panah } \\
\text { Merah (hibrida) }\end{array}$ & Not found & 27 \\
\hline $\mathrm{D}$ & $\begin{array}{l}\text { Village Tegalgondo, Sub } \\
\text { district Dau, District } \\
\text { Malang, East Jawa }\end{array}$ & $\begin{array}{l}\text { Moderate } \\
\text { terrain }\end{array}$ & $\begin{array}{c}\text { Cayenne chili, } \\
\text { varieties Dewanta } \\
\text { (hibrida) }\end{array}$ & Mild & 48 \\
\hline E & $\begin{array}{l}\text { Village Tegalgondo, Sub } \\
\text { district Dau, District } \\
\text { Malang, East Jawa }\end{array}$ & $\begin{array}{l}\text { Moderate } \\
\text { terrain }\end{array}$ & $\begin{array}{l}\text { Cayenne chili, } \\
\text { varieties Dewanta } \\
\text { (hibrida) }\end{array}$ & Mild & 35 \\
\hline $\mathrm{F}$ & $\begin{array}{l}\text { Village Gayam, Sub } \\
\text { district Gurah, District } \\
\text { Kediri, East Jawa }\end{array}$ & Lowland & $\begin{array}{c}\text { Cayenne chili, } \\
\text { local varieties } \\
\text { Prenthul Brenggala }\end{array}$ & Moderate & 28 \\
\hline G & $\begin{array}{c}\text { Village Mukuh, Sub } \\
\text { district Kain Kidul, } \\
\text { District Kediri, East Jawa }\end{array}$ & Lowland & $\begin{array}{l}\text { Cayenne chili, } \\
\text { local varieties } \\
\text { Prenthul Pagu }\end{array}$ & Moderate & 19 \\
\hline $\mathrm{H}$ & $\begin{array}{c}\text { Village Babakan, Sub } \\
\text { district Dramaga, District } \\
\text { Bogor, West Jawa }\end{array}$ & Lowland & $\begin{array}{l}\text { Cayenne chili, } \\
\text { unknown varieties }\end{array}$ & Not found & 45 \\
\hline
\end{tabular}

Table 2. The ability of rhizobacterial isolates inhibits the growth of Phytophthora capsici in vitro 7 days after incubation

\begin{tabular}{|c|c|c|c|c|}
\hline $\begin{array}{l}\text { Rhizobacteria } \\
\text { treatment }\end{array}$ & $\begin{array}{c}\text { Radius growth average of } \\
\text { capsici }(\mathrm{cm})\end{array}$ & $P$. & $\begin{array}{l}\text { Inhibition of } \\
\text { capsici (\%) }\end{array}$ & $\begin{array}{c}\text { Width average of } \\
\text { inhibition zone }(\mathrm{cm})\end{array}$ \\
\hline E1 & 2.83 & & $42 \mathrm{a}$ & $2 a$ \\
\hline E3B2 & 3.33 & & $32 \mathrm{~b}$ & $0.23 \mathrm{~b}$ \\
\hline E3C1 & 3.47 & & $29 \mathrm{~b}$ & $0.57 \mathrm{~b}$ \\
\hline $\mathrm{E} 3 \mathrm{C} 2$ & 3.67 & & $25 \mathrm{~b}$ & $0.57 \mathrm{~b}$ \\
\hline F2B1 & 3.76 & & $23 \mathrm{~b}$ & $0.60 \mathrm{~b}$ \\
\hline Control & 4.90 & & - & - \\
\hline
\end{tabular}

The numbers in the same column with the same letters are not significantly different based on Duncan multiple range tests (DMRT) at the level of á $=5 \%$. 
the effectiveness of rhizobacterial inhibition on pathogens involves many mechanisms, one of which relates to the ability of rhizobacterial isolates to secrete extracellular enzymes (chitinase, protease, and cellulase), especially protease and cellulase, and $\mathrm{HCN}$ production. This is also reinforced by the statement of Babalola (2010), that metabolites of hydrogen cyanide ( $\mathrm{HCN}), 2.4$-diacetyl phloroglucinol (DAPG) and siderophore are anti-fungal compounds produced by rhizobacteria.

Purification was carried out on the five selected rhizobacterial isolates, purification was carried out because the color of different bacterial colonies was found so that 12 isolates of rhizobacteria were obtained. The 12 isolates of rhizobacteria were then tested for their inhibitory effect on P. capsici in vitro. Based on the results of testing two cultures, four selected rhizobacterial isolates were E1, E3B, E3C, and F2B. Rhizobacterial isolates of $\mathrm{E} 1$ produced the highest percentage of inhibitory power among all treatments, besides isolates $\mathrm{E} 3 \mathrm{C}, \mathrm{F} 2 \mathrm{~B}$, and $\mathrm{E} 3 \mathrm{~B}$ were able to inhibit $P$. capsici with a percentage of inhibitory power above $10 \%$ so it was selected for further testing. The four isolates were then refined, but E3B isolates could not grow on PDA media (incubation of room temperature for 3-5 days). The three isolates (E1, E3C, and F2B) and their derivatives were then re-tested for their ability to inhibit $P$. capsici.

Syamsuddin (2010) explained that the rhizobacteria group which has low inhibitory power does not even have inhibitory power at all, has the potential to be developed as a growth-boosting rhizobacteria. This rhizobacteria group may have various other abilities, such as producing IAA, cytokines, gibberellins, and ethylene which can function as biostimulants. A number of rhizobacterial isolates resulting from isolation from the rhizosphere of chili plants showed the ability to produce IAA, siderophore compounds and dissolve phosphate. These secondary metabolites are an indicator of the ability of bacteria in their role as PGPR. Therefore rhizobacterial isolates with $P$. capsici medium inhibitory power can be selected and combined (between two or more rhizobacterial isolates), making it possible to combine the ability of rhizobacteria in inhibiting $P$. capsici and increasing plant growth.

\section{Testing the Compatibility of Some Selected Rhizobacterial Isolates. Compatibility test was} conducted on three selected rhizobacterial isolates (Table 3). The reason for using the three isolates is E1 isolate has the highest inhibitory power, while the $\mathrm{E} 3 \mathrm{C} 2$ and F2B1 isolates have moderate inhibition. The three isolates came from location $\mathrm{E}$ (the moderate plain of Malang Regency) and F (the lowland of Kediri Regency). The three locations had a moderate intensity of the attack on P. capsici (the number of plants with symptoms of phytophthora blight was less than 20 , in one planting area), this proves that there are rhizobacteria that can control pathogen $P$. capsici. Isolates E1 and F2B1 were isolates obtained from NA media. $\mathrm{E} 3 \mathrm{C} 2$ isolates were isolates obtained from TSAP media, namely TSA media with heated samples so that the bacteria were suspected to survive at high

Table 3. Three rhizobacterial isolates selected and the ability to inhibit Phytophthora capsici (in vitro)

\begin{tabular}{ccccc}
\hline Sample & Description & $\begin{array}{c}\text { Attack intensity } \\
\text { P. capsici }\end{array}$ & Origin of isolate & $\begin{array}{c}\text { Isolate } \\
\text { medium }\end{array}$ \\
\hline E1 & $\begin{array}{c}\text { Derived from location E } \\
\text { (Village Tegalgondo, Sub district Dau, } \\
\text { District Malang, East Jawa) } \\
\text { (isolate code is Eana3) }\end{array}$ & Mild & Rizoplane & NA \\
E3C2 & $\begin{array}{l}\text { Derived from location E } \\
\text { (Village Tegalgondo, Sub district Dau, } \\
\text { District Malang, East Jawa) } \\
\text { (isolate code is Eatsap1) } \\
\text { F2B1 }\end{array}$ & Mild & Rizoplane & TSAP \\
& $\begin{array}{l}\text { Derived from location F } \\
\text { (Village Gayam, Sub district Gurah, } \\
\text { District Kediri, East Jawa) } \\
\text { (isolate code is Fana9) }\end{array}$ & Moderate & Rizoplane & NA \\
\hline \hline
\end{tabular}


temperatures. According to Syamsudin (2010), isolation of rhizobacteria with Bacillus spp. The target was carried out using TSA media, while for Pseudomonas fluorescent and Serratia spp. using King's B and NA media. The characteristics of the three selected isolates as presented in Table 4.

Hypersensitive test results of rhizobacterial isolates on tobacco plants showed that all three rhizobacterial isolates obtained were not pathogenic in plants (Figure 4). Hypersensitivity test was carried out with the density of $\mathrm{E} 1$ rhizobacterial isolates $(1.95 \times 109$ CFU mL-1), E3C2 (1.37x109 CFU mL-1), and F2B1 (1.99x $\left.10^{9} \mathrm{CFU} \mathrm{mL}-1\right)$. The relatively high bacterial density is carried out because the rhizobacteria collected successfully will be used as seed treatment before planting. According to Bai et al. (2002) and Sutariati et al., (2006a), the application of rhizobacteria from Pseudomonas sp., Bacillus sp., And Serratia sp. Groups, which are recommended in the treatment of seed before planting (biopriming) at a density of $10^{8}$ $10^{9} \mathrm{CFU} \mathrm{mL}-1$, equivalent to the value of the absorbance reading OD600 $=0.072-0.192$ using a spectrophotometer.

The results of the compatibility test between $\mathrm{E} 3 \mathrm{C} 2$ isolates as the first isolate (isolates mixed in PDA media), then on the surface of the media placed dipped paper disc in isolates E1 and F2B1 showed no halo (limiting zone between two rhizobacterial isolates). Based on the results of these three isolates compatible (Table 5). The $\mathrm{E} 1$ isolate as the first isolate against F2B1 isolates did not show any halo and vice versa. However, when E1 isolates as the first isolate were tested with $\mathrm{E} 3 \mathrm{C} 2$ isolates, a halo zone was formed around the $\mathrm{E} 3 \mathrm{C} 2$ isolate. Likewise when isolates F2B1 act as the first isolate. The halo formation showed that $\mathrm{E} 3 \mathrm{C} 2$ isolates were not compatible with $\mathrm{E} 1$ isolates or $\mathrm{F} 2 \mathrm{~B} 1$ isolates. Based on the results of the compatibility test, the three isolates allow being used simultaneously.

The compatibility test of three rhizobacterial isolates showed inconsistent results presumably not a result of the formation of antagonistic compounds between bacteria (Table 5). This is likely due to bacterial competition for space and nutrition, as well as the presence of bacteria that are the first bacteria (bacterial base). According to Fredrickson \& Stephanopoulos (1981), competition between two populations of microorganisms tends to eliminate weak micro-organism populations, but a number of factors reduce competition so that populations of microorganisms can coexist.

Table 6 shows the inhibitory power of rhizobacterial isolates ranging from $33 \%-60 \%$ after 7 days of incubation. The highest inhibitory power and the widest inhibition zone was shown by one isolate and three types of combination isolates, namely E1 isolate $(58 \%)$, combination of isolates E1 + E3C2 (58\%), E1 +

Table 4. Characteristics of rhizobacterial isolate E1, E3C2, dan F2B1

\begin{tabular}{ccccc}
\hline Isolate & Colony color & Colony shape & Edge colony & Elevation colony \\
\hline E1 & White & Round & Entire & Flat \\
E3C2 & Yellow & Round & Entire & Raised \\
F2B1 & Yellowish white & Round & Entire & Flat \\
\hline
\end{tabular}

Table 5. Compatibility of rhizobacterial isolates selected

\begin{tabular}{|c|c|c|}
\hline \multirow[t]{2}{*}{ PDA with rhizobacteria } & \multicolumn{2}{|c|}{ Rhizobacterial isolates (on paper disc) } \\
\hline & $\mathrm{E} 3 \mathrm{C} 2$ & F2B1 \\
\hline \multirow[t]{2}{*}{ E1 } & $\sqrt{ }$ & - \\
\hline & E1 & F2B1 \\
\hline \multirow[t]{2}{*}{$\mathrm{E} 3 \mathrm{C} 2$} & - & - \\
\hline & E1 & $\mathrm{E} 3 \mathrm{C} 2$ \\
\hline F2B1 & - & $\sqrt{ }$ \\
\hline
\end{tabular}

$\sqrt{ }=$ halo (incompatible), $-=$ not formed halo (compatible) 
Table 6. The ability of combination rhizobacterial isolates to inhibit the growth of Phytophthora capsici in vitro 7 days after incubation

\begin{tabular}{lccc}
\hline $\begin{array}{c}\text { Rhizobacteria } \\
\text { treatment }\end{array}$ & $\begin{array}{c}\text { Radius growth average of } \\
P . \text { capsici }(\mathrm{cm})\end{array}$ & $\begin{array}{c}\text { Inhibition of } \\
\text { P. capsici }(\%)\end{array}$ & $\begin{array}{c}\text { Width average of } \\
\text { inhibition zone }(\mathrm{cm})\end{array}$ \\
\hline $\mathrm{E} 1$ & $1.88 \mathrm{~d}$ & $58 \mathrm{a}$ & $1.72 \mathrm{a}$ \\
$\mathrm{E} 3 \mathrm{C} 2$ & $2.90 \mathrm{bc}$ & $35 \mathrm{bc}$ & $0.00 \mathrm{c}$ \\
$\mathrm{F} 2 \mathrm{~B} 1$ & $3.02 \mathrm{~b}$ & $33 \mathrm{c}$ & $0.54 \mathrm{~b}$ \\
$\mathrm{E} 1+\mathrm{E} 3 \mathrm{C} 2$ & $1.88 \mathrm{~d}$ & $58 \mathrm{a}$ & $1.96 \mathrm{a}$ \\
$\mathrm{E} 1+\mathrm{F} 2 \mathrm{~B} 1$ & $1.80 \mathrm{~d}$ & $60 \mathrm{a}$ & $1.90 \mathrm{a}$ \\
$\mathrm{E} 3 \mathrm{C} 2+\mathrm{F} 2 \mathrm{~B} 1$ & $2.72 \mathrm{c}$ & $39 \mathrm{~b}$ & $0.00 \mathrm{c}$ \\
E1 + E3C2 + F2B1 & $1.88 \mathrm{~d}$ & $58 \mathrm{a}$ & $1.80 \mathrm{a}$ \\
Control & $4.48 \mathrm{a}$ & - & - \\
\hline
\end{tabular}

Description: The numbers in the same column with the same letters are not significantly different based on Duncan multiple range tests (DMRT) at the level of $\alpha=5 \%$.
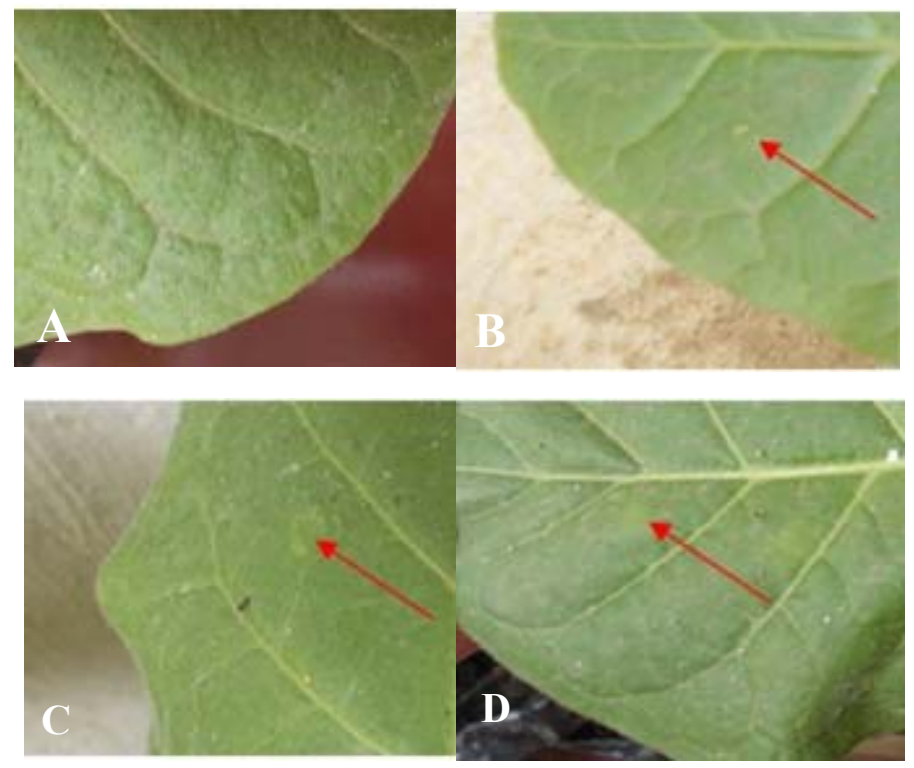

Figure 4. Hypersensitivity test of isolates E1, E3C2, and F2B1 on leaves of tobacco plants. (A) Control (sterile distilled water without rhizobacteria); (B) isolate E1; (C) E3C2 isolates; (D) isolates F2B1.

F2B1 (60\%), and E1 + E3C2 + F2B1 ( 58\%). The average width of the inhibition zone combination of isolates $\mathrm{E} 1+\mathrm{E} 3 \mathrm{C} 2(1.96 \mathrm{~cm}), \mathrm{E} 1+\mathrm{F} 2 \mathrm{~B} 1(1.90 \mathrm{~cm})$, and $\mathrm{E} 1+\mathrm{E} 3 \mathrm{C} 2+\mathrm{F} 2 \mathrm{~B} 1(1.80 \mathrm{~cm})$, was higher than the single isolate E1 $(1.72 \mathrm{~cm})$. From these results, it can be concluded that the combination of rhizobacterial isolates was more effective than single rhizobacterial isolates, in inhibiting $P$. capsici in vitro.

\section{CONCLUSION}

The fungus $P$. capsici was found in all samples of sick plants. The isolates collected were 252 isolates of rhizobacteria, consisting of 78 isolates from rhizosphere soil and 174 isolates from rhizoplane. Three rhizobacterial isolates that have the ability to inhibit $P$. capsici in vitro, namely isolates $\mathrm{E} 1, \mathrm{E} 3 \mathrm{C} 2$, and $\mathrm{F} 2 \mathrm{~B} 1$. Isolate E1 from rhizoplane of chili plant in Tegalgondo Village, Kecamata Dau, Kabupaten Malang, East Java 
has a higher inhibitory power than isolates $\mathrm{E} 3 \mathrm{C} 2$ and F2B1. The combination of isolates E1 + E3C2, E1 + F2B1, and E1 + E3C2 + F2B1, was able to inhibit $P$. capsici with an average width of the inhibition zone higher than the single isolate $\mathrm{E} 1$.

\section{ACKNOWLEDGMENTS}

Gratitude was conveyed to Kemenristek DIKTI through Penelitian Strategi Nasional Tahun 2015 program for the research funds that have been given, and Balai Penelitian Tanaman Rempah dan Obat (Balitro) for the facilities that have been provided as well as for all those who have assisted in completing this research.

\section{REFERENCES}

Agarwal VK \& Sinclair JB. 1997. Principle of Seed Pathology. Second edition. CRC Press Inc, Boca Raton Florida.

Aminullah, Rachmadiarti F, \& Trimulyono G. 2015. Isolasi dan karakterisasi rhizobakteri pada akar Rhizopora mucronata yang terpapar logam berat timbal (Pb). LenteraBio 4 (1): 43-49.

Aravind R, Kumar A, Eapen SJ \& Ramana KV. 2008. Endophytic bacterial flora in root and stem tissues of black pepper (Piper nigrum L.) genotype: isolation, identification and evaluation against Phytophthora capsici. Lett. Appl. Microbiol. 48(1): 58-64.

Babadoost M. 2004. Phytophthora blight: a serious threat to cucurbit industries. APSnet Feature. The American Phytopathological Society: 1-12.

Bai Y, Pan B, Charles TC, \& Smith DL. 2002. Coinoculation dose and root zone temperature for plant growth promoting rhizobacteria on soybean [Glycine max (L.) Merr] grown in soil-less media. Soil Biol Biochem. 34(12):1953-1957.

Babalola OO. 2010. Beneficial bacteria of agricultural importance. Biotechnol Lett 32: 1559-1570.

[BBPPSLP] Balai Besar Penelitian dan Pengembangan Sumberdaya Lahan Pertanian. 2007. Metode Analisis Biologi Tanah. Saraswati R, Hesen E, Simanungkalit RDM (Eds). Balai Besar Penelitian dan Pengembangan Sumberdaya Lahan Pertanian. Badan Penelitian dan Pengembangan Pertanian. Departemen Pertanian.
Chaerani, Koerniati S, \& Manohara D. 2013.Analisis keragaman genetik Phytophthora capsici Leonian asal lada (Piper nigrum L.) menggunakan penanda molekuler. J. Littri 19 (1): $23-32$.

Fredrickson AG \& Stephanopoulos G. 1981. Microbial Competition. Science. 213(4511): 972-979.

Hausbeck MK \& Lamour KH. 2004. Phytophthora capsici on vegetable crops: research progress and management challenges. Plant Dis. 88(12): 12921303.

Ibrahim A, Ilyas S, \& Manohara D. 2014. Perlakuan benih cabai (Capsicum annuum L.) dengan rizobakteri untuk mengendalikan Phytophthora capsici, meningkatkan vigor benih dan pertumbuhan tanaman. Bul Agrohorti. 2(1):2230.

Khan AA, Jilani G, Akhtar MS, Naqvi SMS \& Rasheed M. 2009. Phosphorus solubilizing bacteria: occurrence, mechanisms and their role in crop production. J. Agric. Biol. Sci. 1(1): 48-58.

Lamour KH \& Hausbeck MK. 2001. Investigating the spatiotemporal genetic structure of Phytophthora capsici in Michigan. Phytopathology 91: 973-980.

Lim JH \& Kim SD. 2010. Biocontrol of phytophthora blight of red pepper caused by Phytophthora capsici using Bacillus subtilis AH18 and B. licheniformis K11 formulations. J Korean Soc. Appl. Biol. Chem. 53(6): 766-773.

Louws FJ, Holmes GJ \& Ristaino JB. 2002. Phytophthora blight of pepper and cucurbits; vegetable disease information note 27: College of Agriculture and Life Science, Plant Pathology Extension, North Carolina State University: 1-4.

Madigan TM, Martinko JM, \& Parker J. 2003. Brock Biology of Microorganisms 10th ed. Pearson Education Inc., New Jersey.

Majeed A, Abbasi MK, Hameed S, Imran A, \& Rahim N. 2015. Isolation and characterization of plant growth-promoting rhizobacteria from wheat rhizosphere and their effect on plant growth promotion. Front. Microbiol. 6(198): 1-10.

Manohara D. 1988. Ekologi Phytophthora palmivora (Bulter). Penyebab Penyakit Busuk Pangkal Batang Lada (Piper nigrum L.) Disertasi. Institut Pertanian Bogor. 
Manohara D, Mulya K \& Wahyuno D. 2004. Phytophthora disease on black pepper and the control measures. Focus on Pepper 1: 37-49.

Manohara D, Wahyuno D, \& Noveriza R. 2005. Penyakit busuk pangkal batang tanaman lada dan strategi pengendaliannya [internet]. Research Gate: 41-51. [diunduh pada 26 Oktober 2016]. Tersedia pada: https://www.researchgate.net/ publication/2929705 94

Meitz JC, Linde CC, Thompson A, Langenhoven S \& McLeod A. 2010. Phytophthora capsici on vegetable hosts in South Africa: distribution, host range, and genetic diversity. Australas Plant Pathology 39: 431-439.

Purwantisari S \& Hastuti RB. 2009. Uji antagonisme jamur patogen Phytophthora infestans penyebab penyakit busuk daun dan umbi tanaman kentang dengan menggunakan Trichoderma spp. Isolat Lokal. Bioma. 11(1): 24-32.

Retnosari E, Henuk JBD, \& Sinaga MS. 2014. Identifikasi penyebab penyakit busuk pangkal batang pada jeruk. J. Fitopatol. Indonesia. 10(3): 93-97.

Rosadiah NF, Ilyas S, \& Manohara D. 2015. Perlakuan benih cabai (Capsicum annuum L.) dengan rizobakteri secara tunggal atau kombinasi dapat mengendalikan Phytophthora capsici dan meningkatkan pertumbuhan tanaman. J. Hort. Indonesia 6(1): 1-10.

Sutariati GAK, Widodo, Sudarsono, \& Ilyas S. 2006a. Karakter fisiologis dan keefektifan isolat rizobakteri sebagai agens antagonis Colletotrichum capsici dan rizobakteri pemacu pertumbuhan tanaman cabai. J. Ilmiah Pertanian Kultura 41(1): 28-34.

Sutariati GAK, Widodo, Sudarsono \& Ilyas S. 2006 b. Pengaruh perlakuan rizo bakteri pemacu pertumbuhan tanaman terhadap viabilitas benih serta pertumbuhan bibit tanaman cabai. Bul. Agron. 34(1): 46-54.

Syamsuddin. 2010. Perlakuan Benih untuk Pengendalian Penyakit Busuk Phytophthora, Peningkatan Hasil dan Mutu Benih Cabai Merah (Capsicum annuum L). Disertasi. Institut Pertanian Bogor. Bogor.

Wahyuno D. 2009. Pengendalian terpadu busuk pangkal batang lada. Perspektif. 8(1): 17-29.

Watanabe T. 2002. Pictorial Atlas of Soil and Seed Fungi (morphologies of cultures fungi and key to species). Second edition. London (GB), New York, Washington DC (US): CRC press.

Yamaguchi I. 1996. Pesticides of Microbial Origin and Applications of Moleculer Biology. Crop protection Agents From Nature: Natural Products and Analogues. The Royal Society Chemistry, London, United Kingdom (GB). 